\title{
THE REPRODUCTIVE CAPACITY OF PANSTRONGYLUS MEGISTUS (HEMIPTERA: REDUVIIDAE) MALES TREATED WITH PRECOCENES
}

\author{
VÂNIA M. S. CAVALCANTE/ ${ }^{+}$\& LÊDA N. REGIS*
}

\begin{abstract}
Centro de Pesquisas Aggeu Magalhães-FIOCRUZ, Campus UFPE, 52020-020 Recife, PE, Brasil *Universidade Federal de Pernambuco, Departamento de Zoologia 52020-020 Recife, PE, Brasil
\end{abstract}

Reproductive performance including mating, semen transfer, egg production and hatching rate were investigated in pairs of Panstrongylus megistus in which the male was treated with either precocene II or ethoxyprecocene II, topically applied shortly after imaginal molt. Eighty percent of the males were not able to mate for a period as long as 40 days after treatment. Those males which did mate (20\%) produced small spermatophores; a few (10\%) were unable to transfer spermatozoa to female, while the others (10\%) exhibited reproductive performance similar to that of non-treated males. The cumulative effects of the precocene on the different stages of reproduction resulted in a drastic reduction of offspring production. The anti-allatal compound precocene seems to inhibit successful reproduction through a corpus allatum inactivation and subsequent lack of secretory activity of the male accessory glands.

Key words: reproduction - Panstrongylus megistus - precocene

Male insect accessory secretions play an important role in reproduction, including spermatophore and seminal fluid production, spermatozoa maintenance and activation as well as influencing female behaviour and physiology (Leopold, 1976). Males cannot transfer gametes before accumulating the necessary amount of secretion in their accessory glands. For instance, Panstrongylus megistus males have spermatozoa at the base of testicular follicles before the imaginal molt (IM) takes place (Schuetz, 1988). Movement to the seminal vesicles occurs two days after emergence. However the males are generally not able to mate successfully before eight days after IM, when the male accessory glands (MAG) have accumulated a large amount of secretion products in their lumina (Regis et al., 1985). It has been shown in many insect species that juvenile hormone $(\mathrm{JH})$ plays a role in activation of MAG secretory activity (Blaine \& Dixon, 1973; Herman, 1975; Gillot \& Friedel, 1976). In P. megistus (Regis et al., 1987) as well as in Rhodnius prolixus (Barker \& Davey, 1981), both $\mathrm{JH}$ and cerebral neurosecretion are essential to MAG activity. In $P$. megistus, Regis et

Supported by CNPq Brazil. Grant 500045/88-7.

${ }^{+}$Research fellowship.

Received 5 March 1992.

Accepted 17 August 1992. al. (1987) have shown that JH directly stimulates the synthesis of most accessory secretion proteins and that the synthesis of small molecules (polypeptides) possibly results from a direct action of neurosecretory products on MAG. In this species, MAG secretory activity in males treated by anti-allatal compound precocene II (PII) is higher than that of allatectomized males, but the storage of secretory products in MAG lumen in PII treated males, is reduced to about $50 \%$ of that in control groups (Regis et al., 1985). The eletrophoretic pattern of PII treated male secretions shows five bands, which are absent in corpus allatum (CA) deprived males of the same age (Regis et al., 1987).

In order to investigate if the secretion accumulated in the MAG lumen of precocene treated males is sufficient for spermatophore production and to promote sperm transfer, reproductive performance was evaluated by pairing them with untreated females.

\section{MATERIALS AND METHODS}

Insects $-P$. megistus fifth instar nymphs from our stock colonies have been used. They were fed on Gallus sp and kept in $28^{\circ} \mathrm{C}$ incubator with $70-80 \%$ relative humidity.

Experimental groups - PII from SIGMA was donated by Dr Marie Raabe (Paris VI Uni- 
versity) and ethoxyprecocene II (EPII) was a gift from Dr Gerard Wyatt (Queen University, Canada). Precocenes were diluted in acetone and applied topicaly on abdominal tergites, 0 to $6 \mathrm{hr}$ after the imaginal molt (IM) according to the dating method established by Brasileiro \& Regis (1992). Groups of 10 to 14 pairs were formed; male and female were kept isolated from the emergence to the time of mating eight days later. Males were treated with either P II, EP II or acetone. Each male was put together with a female soon after they have taken their first blood meal. They were kept together until the end of the experiment and were fed every 10 days. Because of the precocene antifeedant effect (Slama, 1978; Azambuja et al., 1982) the size of the blood meal was evaluated by weighing 20 males shortly before and after every meal over their lifetime.

Evaluation of precocene effects - the reproductive performance was evaluated by two groups of parameters: (i) mating ability, i.e., storage of secretory products in the MAG, sperm accumulation in seminal vesicles and mating behaviour (ii) mating effectiveness: spermatophore elimination by the female, presence of sperm in the spermathecae, egg production and hatching rate.

Mating - male and female were observed for $3 \mathrm{hr}$ after they were put together in order to record mating behaviour. Elimination of a spermatophore by the female was taken as a proof that mating had occurred.

The presence or absence of spermatozoa in both seminal vesicles and spermathecae was recorded by direct observation under stereoscopic microscope. The storage of secretory products in MAG was evaluated as previously described (Regis et al., 1985). In order to determine the size of the CA, we used a camera lucida attached to a light microscope to drawn an outline of the organ before measuring the drawn area with a planimeter. For histological studies CA were kept in Bouin fixative for $2 \mathrm{hr}$, embedded in agar-paraffin and 6 $\mu \mathrm{m}$ sections were stained by hematoxylin-eo$\sin$.

\section{RESULTS}

Mating ability - during the first $3 \mathrm{hr}$ after being put together with a female, precocene treated males did not mate, although control males have mated whithin this time. In order to verify the occurrence of mating by spermatophore elimination, subsequent observations repeated many times a day have shown that the number of males able to copulate for a period of 40 days after IM was very low, about $20 \%$, in the groups treated by either $300 \mu \mathrm{g}$ of PII or $30 \mu \mathrm{g}$ of EPII (Table). Also, in the groups followed-up for 20 days, the ability of acetone treated males to copulate was higher than that of P II treated males. Furthermore, spermatophore produced by treated males were smaller than those from the control groups, respectively 1.0 and $1.8 \mathrm{mg}$ (Fig. 1). The data obtained from measurement of MAG area (not shown here) were very heterogenous, especially in precocene treated groups where in some males the MAG were completly empty at the end of the experiment (Fig. 2). Spermatozoa storage in the seminal vesicles examined at dissection, do not appear to have been disturbed by precocene treatment; no differences between the groups were noticed.

On day 20 , the CA area in treated males $\left(80.64 \pm 45.73 \mu \mathrm{m}^{2}\right)$ was far smaller than that observed in control males $\left(198.9 \pm 60.21 \mu \mathrm{m}^{2}\right)$ and the gland outline was very irregular. On day $40, \mathrm{CA}$ area in treated males (107.2 \pm $91.1 \mu^{2}$ ) was greater than that observed on day 20. Histological studies showed that at 20 days after PII treatment, there was a significant reduction in cytoplasm volume, the nuclei being very close together. On day $40 \mathrm{CA}$ parenchymal tissues were markedly invaded by tracheae and connective tissues. Most CA secretory cells were disrupted. Many pycnotic nuclei were seen and only in a few small sites there were some intact cells (Fig. 3).

Mating effectiveness - In the treated group observed for 20 days after IM, a normal amount of semen was transferred in only one of the seven pairs that copulated. Three males transferred a small amount of semen to the females, whereas the other three males transferred no semen at all although spermatophores had been produced. At 40 days after IM, semen transfer occurred in most of the couples that have copulated and only one male was not able to inseminate the female. In untreated insects as well as in acetone-treated groups, semen transfer occurred in all the matings (Table).

Analysis of the fecundating capacity was based on egg hatching rate. The number of eggs collected during 50 days after IM was 
TABLE

Mating, semen transfer, egg production and hatching rate in Panstrongylys megistus couples whose male was treated by PIl or EPII at imaginal moult

\begin{tabular}{|c|c|c|c|c|c|c|c|c|c|c|}
\hline \multirow{2}{*}{$\begin{array}{c}\text { Treatment } \\
\mu \mathrm{g} / \text { male }\end{array}$} & \multirow{2}{*}{$\begin{array}{c}\text { Period of } \\
\text { study } \\
\text { (days) }\end{array}$} & \multirow{2}{*}{\multicolumn{2}{|c|}{$\begin{array}{l}\text { No. of } \\
\text { couples }\end{array}$}} & \multicolumn{2}{|c|}{$\begin{array}{l}\text { Semem } \\
\text { transfer }\end{array}$} & \multicolumn{2}{|c|}{ Egg/couple } & \multirow{2}{*}{$\begin{array}{l}\text { Hatching } \\
(\%)\end{array}$} & \multicolumn{2}{|c|}{$\mathrm{Nl} /$ couple } \\
\hline & & & & & & $c$ & $d$ & & $c$ & $d$ \\
\hline EPII 20 & 40 & 10 & 7 & 7 & 0 & $25.0 \pm 27.8$ & $34.7 \pm 28.1$ & 80.7 & $9.0 \pm 13.5$ & $12.8 \pm 14.7$ \\
\hline EPIl 30 & 40 & 10 & 2 & 1 & 1 & $2.0 \pm 5.9$ & $10.0 \pm 12.7$ & 90.0 & $1.8 \pm 5.6$ & $9.0 \pm 12.7$ \\
\hline PII 300 & 20 & 14 & 7 & 4 & 3 & 0 & 0 & 0 & 0 & 0 \\
\hline PII 300 & 40 & 14 & 3 & 3 & 0 & $7.4 \pm 13.0$ & $25.3 \pm 18.0$ & 61.5 & $4.5 \pm 12.2$ & $21.3 \pm 20.8$ \\
\hline- & 40 & 13 & 11 & 11 & 0 & $16.1 \pm 17.9$ & $19.1 \pm 17.9$ & 77.1 & $12.4 \pm 16.3$ & $14.7 \pm 16.8$ \\
\hline acetone & 20 & 12 & 8 & 8 & 0 & $7.7 \pm 6.5$ & $11.5 \pm 4.3$ & 52.6 & $4.0 \pm 3.5$ & $6.1 \pm 2.2$ \\
\hline
\end{tabular}

$a$ : total sample; $b$ : number of couple that have copulated; $c$ : mean from $a . d$ : mean from $b ; \mathrm{N} 1$ : first instar nymph.

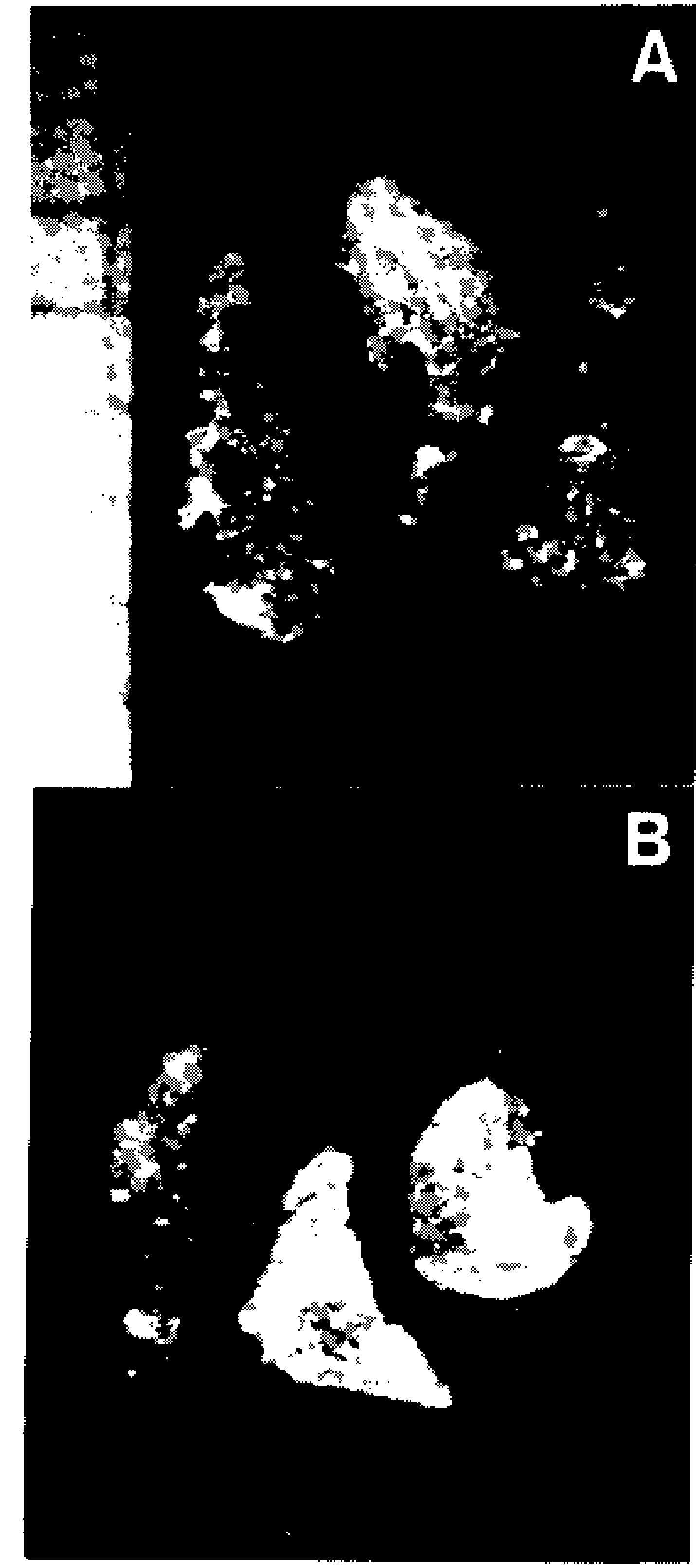

Fig. 1: spermatophores produced by Panstronglus megistus males. A: control group. B: precocene II treated group.

smaller in the precocene-treated groups (Table), however the average number of eggs produced per couple which copulated did not differ statistically from that of the control groups. EPII

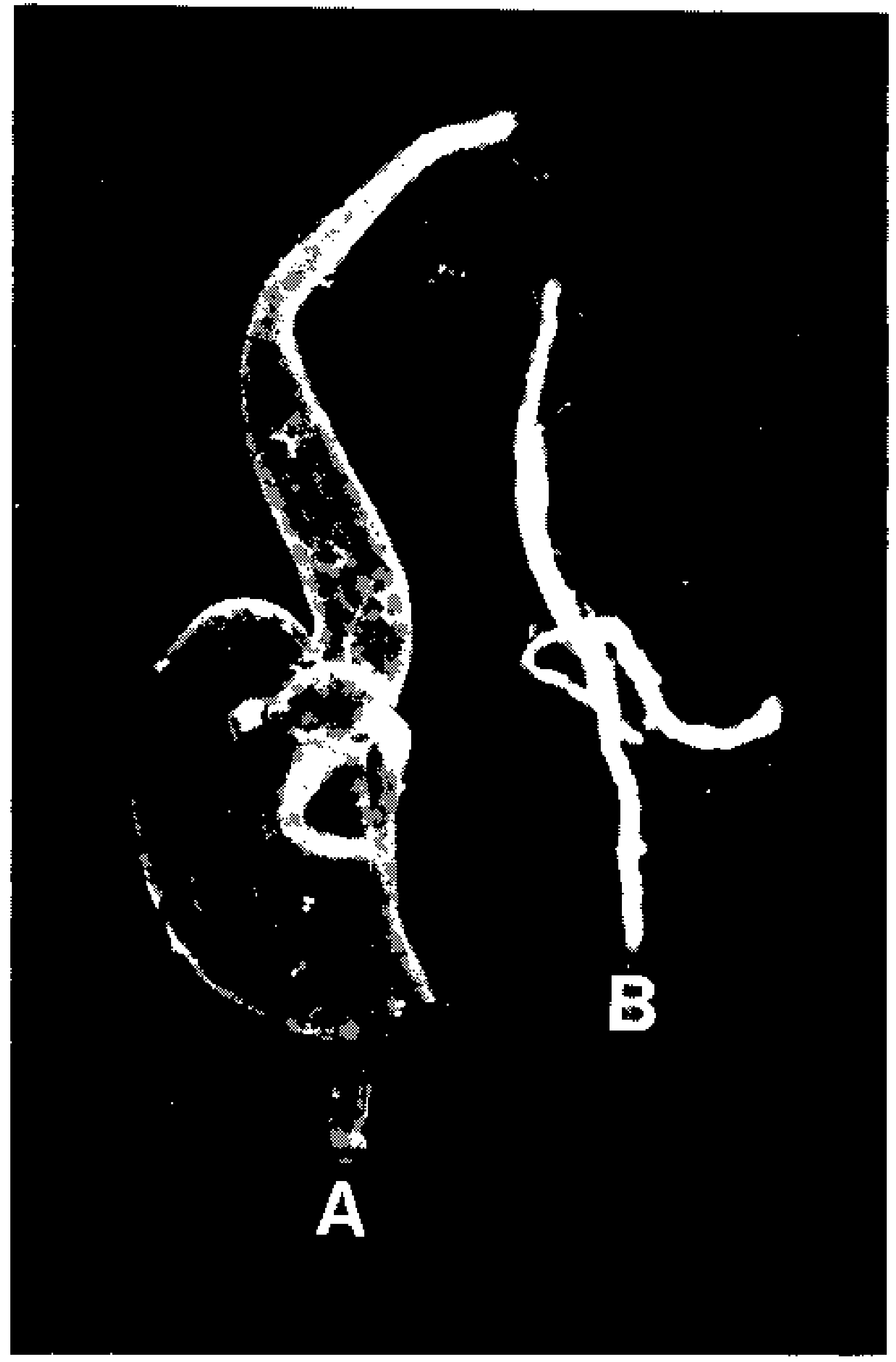

Fig. 2: Panstrongylus megistus male accessory glands. A: full, from a control male. B: empty, from a precocenetreated male.

applied to male had no effect on egg hatching (Table), but eggs layed by females that have mated with PII-treated male had a decreased but no significative hatching rate: $61.5 \%$, against $77.1 \%$ in control.

The cumulative effects of precocenes on the different stages of reproduction-mating, insemination, egg production and hatching are reflected in the number of first instar nymphs 


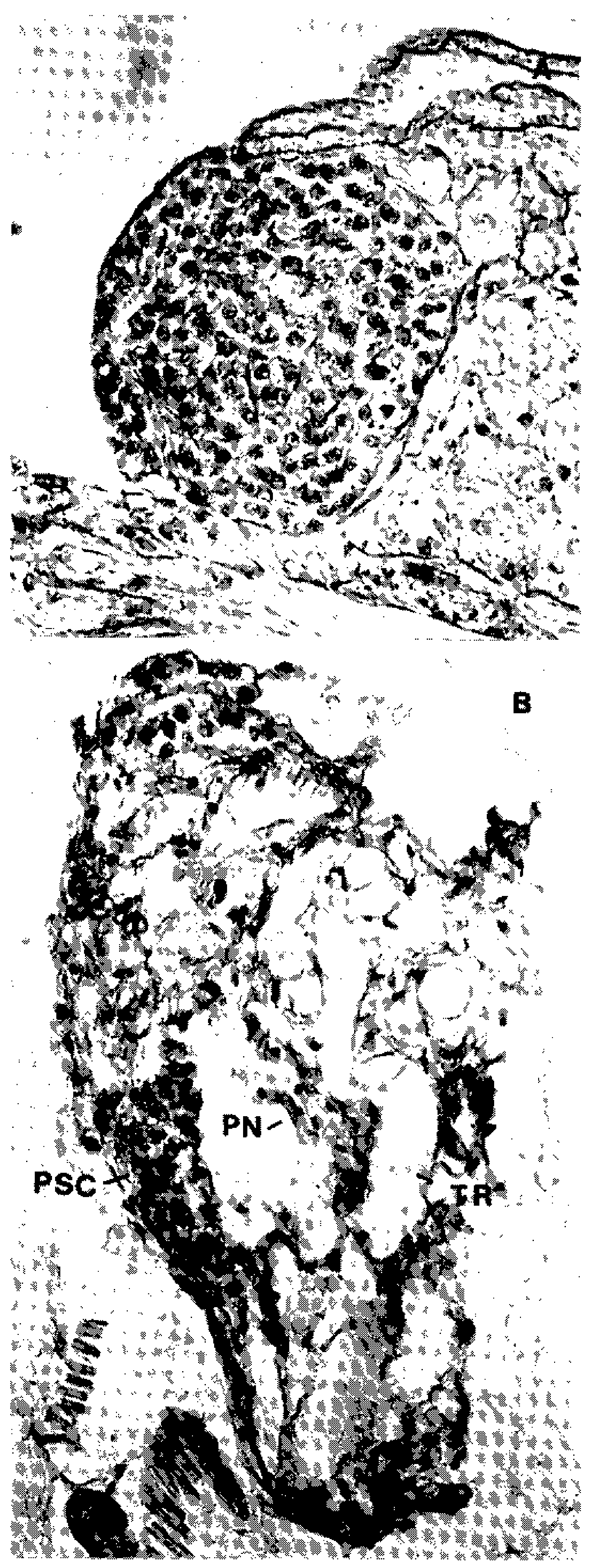

Fig. 3: corpora allata from Panstrongy/us megistus males at 40 days after imaginal molt. $A$ : control group. $B$ : precocene treated group. tr: tracheae; psc: parenchimal secretory cell; pn: picnotic nuclei.

produced per couple in the different groups (Table). In 20-days-experiments, PII treated group did not produce offspring whereas acetone trcated group produced a mean number

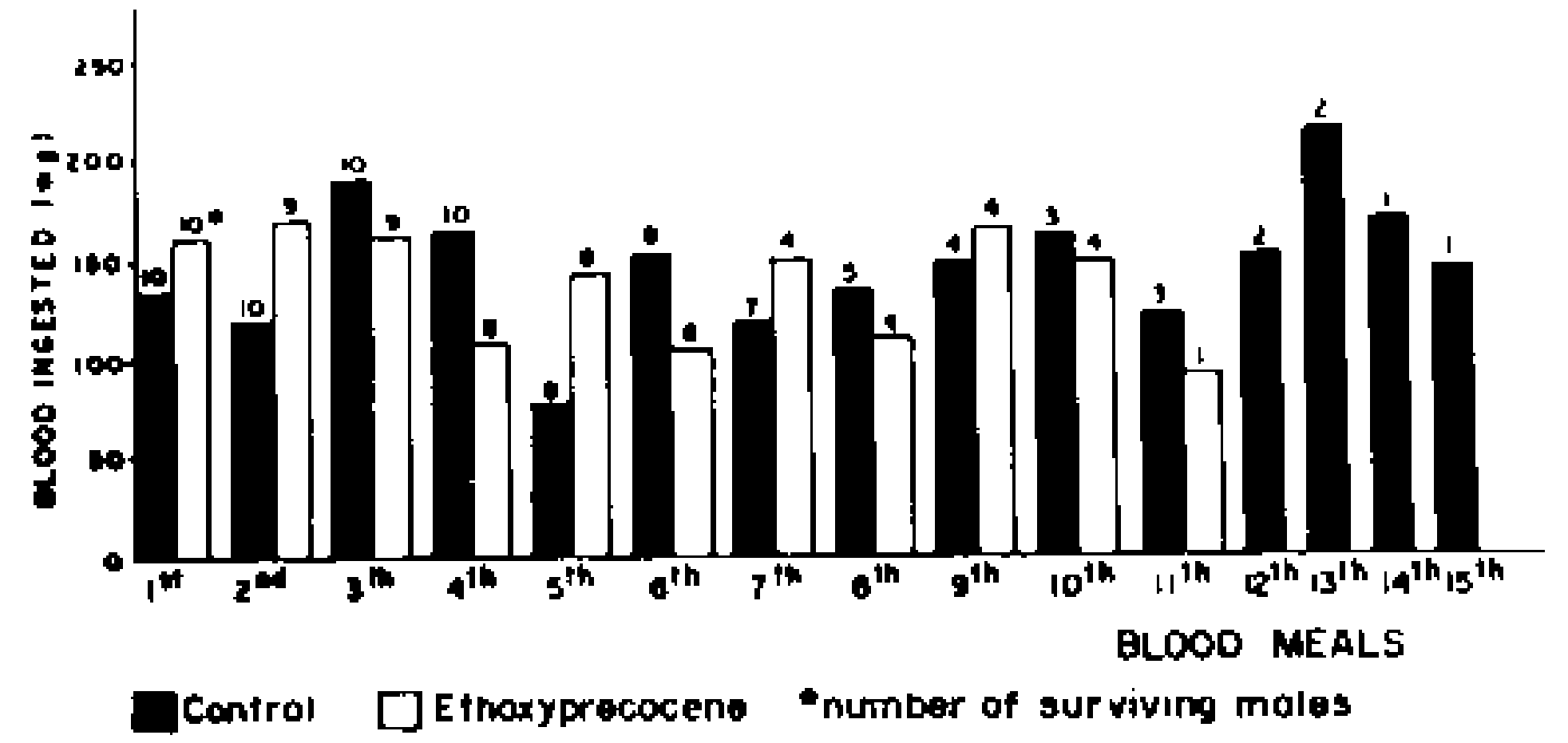

Fig. 4: amount of blood ingested per blood meal, every 10 days, by untreated and ethoxyprecocene treated Panstrongylus megistus males during adult lifetime.

of four first instar nymphs per couple. In 40days-experiments a marked reduction of the offspring production was noticed. In EPII treated group $(30 \mu \mathrm{g})$, production of nymphs from eggs collected over 50 days was only $14.5 \%$ of the control production, i.e. 1.8 first instar nymphs per couple in treated group, while control couples produced an average of 12.4. Nevertheless, analysis of the data from only those treated couples where mating and insemination had normally occurred, shows that nymph production was similar to that in the control group.

In order to investigate the possible effects of precocene on food intake, two groups of 10 couples were formed using treated or nontreated males. Blood meals size was determined by weighing the males shortly before and after every blood meal during their lifetime.

The average amount of blood ingested by precocene treated males (134.82 $\pm 27 \mathrm{mg}$ of $\mathrm{blood} / \mathrm{male} / \mathrm{meal}$ ) throughout their lifetime did not differ from that of control males (144.59 \pm $31.67 \mathrm{mg}$ ) (Fig. 4). Nevertheless, treated males survived only an average of $82.5 \pm 41.1$ days while untreated males $102.6 \pm 50.2$ days.

\section{DISCUSSION}

It has been reported for some insect species that disturbances in mating behaviour after precocene treatment result from lack of a pheromone, whose production is $\mathrm{JH}$ dependent (Judson et al., 1979; Chang \& Hsu, 1982; Baldellou et al., 1984). Very little information is available about pheromones in triatomine bugs. Neves \& Paullini (1981) have suggested for P. megistus and Triatoma infestans that both male and female produce a sex pheromone, but no information about its endocrine 
regulation is available. Therefore, the data on this subject does not allow us to attribute the effects of precocenes on mating to interference with production of a sex atractant.

In addition, the lack of pheromone could neither explain the occurrence of mating without semen transfer, nor the small size of spermatophore produced by the few males which were able to copulate. These effects seem rather to be due to the low secretory activity of MAG in treated males. We have previously shown that precocene causes a strong reduction in the storage of secretory products in the MAG (Regis et al., 1985, 1987). The severe structural changes observed in CA tissues confirm the action of precocene on $\mathrm{JH}$ production in treated males. The histological disturbances observed in this study are similar to those described by Unnithan et al. (1977) in PII treated Oncopeltus fasciatus.

The average number of eggs laid per female, in both PII and EPII treated groups, was lower than that in control groups. This reduction is due to the fact that some females remained virgins although they have been kept with treated male for 20 or even 40 days. It is known that in Triatomine egg laying rate of virgin females is lower than that of mated females (Davey, 1965; Furtado, 1977; Regis, 1979; Brasileiro, 1982). The egg laying rate of those treated couples, in which copulation did occur was not different from the control. Therefore, the reduced egg laying rate of the treated groups seems to be a consequence of the lack of copulation.

Another effect of the precocene treatment was reduction in the egg hatching rate. The lack or decrease of some MAG product related to sperm activation and/or its maintenance in the spermathecae could be responsible for this effect. Unfortunately, there is no knowledge available about this probable function of the accessory secretion in Triatomine bugs.

The cumulative effects of precocene on mating, egg laying and hatching rate resulted in a marked disturbance of the reproductive performance reflected in a drastic decrease of offspring production. These data show a role of $\mathrm{JH}$ on male reproduction on the regulation of MAG activity and also indicate that some important functions of the male accessory products in Triatomine bugs remain to be elucidated.
Analysis of the data gathered from each couple indicates that males treated with the same precocene dose, can respond in three different ways: (a) the majority $(80 \%)$ is unable to copulate; (b) some males $(10 \%)$ can mate but they produce small spermatophores and transfer few or no sperm; (c) reproductive performance of some males $(10 \%)$ remains quite normal. Therefore some males appear to be non-sensitive to precocenes, while others show different degree of sensitivity. Different sensitivity to precocenes has been found in most of the heterometabolous species studied (Bowers \& Aldrich, 1980; Pener, 1987). All the Reduviidae species studied, as $R$. prolixus (Tarrant \& Cupp, 1978), $T$. infestans (Jurberg et al., 1986), T. dimidiata (Tarrant et al., 1982), P. megistus (Brasileiro, 1987) are, in different rate sensitive to precocenes. Our results show that in $P$. megistus also there are different levels of individual sensitivity. They allow us to determine that a decrease on MAG activity after precocene treatment can have some consequences on reproductive performance. The reproductive performance in treated groups was drastically reduced. Treated and untreated males were able to ingest a similar amount of blood, discarding the possibility that lack of food could be responsible for the effects observed on reproduction. The results also allow us to discard any interference of the solvent used (acetone). Despite the fact that absence of $\mathrm{JH}$ in adult males does not affect sperm production, this hormone plays an important role on male reproductive capacity regulation.

Precocious metamorphosis and sterilization of adult females after exposition to precocenes have been reported in several insect species, including Triatomine bugs (Azambuja \& Garcia, 1991). Our present data on P. megistus show that those allatotoxins can induce sterilization of adult males as well.

\section{REFERENCES}

AZAMBUJA, P. D.; BOWERS, W. S.; RIBEIRO, J. C. M. \& GARCIA, E. S., 1982. Antifeedant activity of precocenes and analogs on Rhodnius prolixus. Experientia, 38: 1054-1055.

AZAMBUJA, P. \& GARCIA, E. S., 1991. Effects of Proallatotoxins (Precocenes) on the development and reproduction of Rhodnitus prolixus: some data. Mem. Inst. Oswaldo Cruz, 86 (Suppl. II): 113-115.

BALDELLOU, M. I.; BELLES, X. \& PIULACHS, M. D., 1984. Influence du traitement par des précocènes sur le comportement sexuel d'Oxicarenus lavaterae (F) (Heteroptera: Lygaeidae) et de Blatera germanica (L) (Dictioptera: Blattellidae), p. 53-56. In A. 
de Haro \& X. Espadaler (eds). Processus d'aquisition précoce. Les communications. Universitat Autonoma de Barcelona et Societé Française pour létude du comportement animal.

BARKER, J. F. \& DAVEY, K. G., 1981. Neuroendocrine regulation of protein accumulation by the transparent accessory reproductive gland of male Rhodnius prolixus. Int. J. Invert. Reprod., 3: 291 296.

BLAINE, N. D. \& DIXON, S. E., 1973. The effect of juvenile hormone on the function of the accessory glands of the adult male cockroach Periplaneta americana (Orthoptera; Blatiidae). Can. Ent., 105: 1275-1290.

BOWERS, W. S. \& ALDRICH, J. R., 1980. In vivo inactivation of denervated corpora allata by precocene II in the bug Oncopeltus fasciatus. Experientia, 36: $362-363$.

BRASILEIRO, V. L. F., 1982. Fecundidade e fertilidade da fêmea de Triatoma brasiliensis (Hemiptera; Reduviidae). Influência da cópula e da longevidade. Rev, Bras. Biol, 42: 1-13.

BRASILEIRO, V. L. F., 1987. Efeitos do tratamento da ninfa fêmea do quinto estádio de Panstrongylus megistus (Hemiptera: Reduviidae) com precoceno II: I. Conseqüências sobre a fecundidade e fertilidade na fase adulta. Rev. Bras. Ent, 31: 131-134.

BRASILEIRO, V. L. F. \& REGIS, L. N., 1992. Evolution of the cuticular pigmentation as a dating system for Panstrongylus megistus and Rhodnius prolixus adults. Insect Sci. Applic., 13: 231-240.

CHANG, F. \& HSU, C. L., 1982. Effect of precocene II on sex attractancy in the Mediterranean fruit fly Ceratitis capitata (Wiedemann). Ann. Entmol. Soc. Am., 75: 38-42.

DAVEY, K. G., 1965. Copulation and egg-production in Rhodnius prolixus. The role of spermathecae. $J$. exp. Biol., 42: 373-378.

FURTADO, A. F., 1977. Contrôle endocrine des mitoses goniales et du declenchement de la meiose chez la female de Panstrongylus megistus (Hemiptera: Reduviidae). Thèse (Docteur ès Sciences) - Université Pierte et Marie Curie, Paris VI, 159 p.

GILLOTT, C. \& FRIEDEL, T., 1976. Development of accessory reproductive glands and its control by corpus allatum in adult male Melanoplus sanguinipes. J. Insect Physiol., 22: 365-372.

HERMANN, W. S., 1975. Juvenile hormone stimulation of tubular and accessory glands of male monarch butterflies. Comp. Biochem. Physiol, SIA: 507 . 510.

JURBERG, J.; COSTA, J. M.; GONÇALVES, T. C. M.; GARCIA, E. S. \& AZAMBUJA, P., 1986. Alterações biomorfogênicas causadas pela aplicação de precoceno II em ninfas de Triatoma infestans (Klug, 1834) (Hemiptera: Reduviidae, Triatominae) $\mathrm{Mem}$. Inst. Oswaldo Cruz, 81: 171-184.

JUDSON, P.; KISHEN, R. B.; THAKUR, S. S. \& REVATY, P., 1979. Effect of precocene II on reproduction of the bug Dysdercus similis (F) (Hemiptera). Indian J. Exp. Biol., I7: 947-949.

LEOPOLD, A. R, 1976. The role of male accessory glands in insect reproduction. Annu. Rev. Entomol, 2l: 199-221.

NEVES, D. P. \& PAULLINI, E., 1981. Atração sexual em Panstrongylus megistus e Triatoma infestans (Hemiptera: Reduviidae) por feromônio. Rev. Bras. Ent., 25: 301-306.

PENER, M. P., 1987. Effects and applied potential of anti-hormones in acridid, p. 400-413. In Evolutionary Biology of Orthopteroid Insects. Ellis Horwood Ltd., England.

REGIS, L., 1979. The role of the blood meal in egglaying periodicity and fecundity in Triatoma infestans. Int. J. invert. Reprod., I: 187-195.

REGIS, L. N.; FURTADO, A. F.; GOMES, Y. M.; COUTINHO, V. B.; SCHUETZ, M. J. C.; CAVALCANTE, V. M. S.; BRITO, M. E. \& COUTINHO, H. B., 1987. Secretory activity and endocrine regulation of male accessory glands in the blood sucking bug Panstrongylus megistus (Hemiptera: Reduviidae). Mem. Inst. Oswaldo Cruz, 82. Supl. III: 75-78.

REGIS, L.; GOMES, Y. M. \& FURTADO, A. F., 1985. Factors influencing male accessory gland activity and first mating in Triatoma infestans and Panstrongylus megistus (Hemiptera: Reduviidae). Insect Sci. Appilc., 6: 579-583.

SLAMA, K., 1978. The principles of antihormone action in insects. Acta Entomol. Bohemoslovaca, 75 : 65-82.

SCHUETZ, M. J. C., 1988. Desenvolvimento e diferenciação das células germinais em macho de Panstron gylus megistus (Hemiptera: Reduviidae). Mem. Inst. Oswaldo Cruz, $8 \dot{3}$ (Suppl. I): 189.

TARRANT, C., \& CUPP, E. W., 1978. Morphogenetic effects of precocene II on the immature stages of Rhodnius prolixus. Trans. R. Soc. Trop. Med. Hyg., 72: 666-668.

TARRANT, C.; CUPP, E. W. \& BOWERS, W. S., 1982. The effects of precocene II on reproduction and development of triatominae bugs (Reduviidae: Triatominae). Am. J. Trop. Med. Hyg., 31: 416-420.

UNNITHAN, G. C.; NAIR, K. K \& BOWERS, W. S., 1977. Precocene-induced degeneration of the corpus allatum of adult fermales of the bug Oncopelthus fasciatus. J. Insect Physiol., 23: 1081-1094. 